\title{
NATURAL RADIOACTIVITY AND DOSE ASSESSMENT IN SAND AND SEDIMENT SAMPLES FROM KUAKATA BEACH, BANGLADESH
}

\author{
MD. MURAD AHMED, SURANJAN KUMAR DAS*, SARIFUL AND \\ SELINA YEASMIN ${ }^{1}$ \\ Department of Physics, Jagannath University, Dhaka, Bangladesh
}

\begin{abstract}
The activity concentrations of radionuclides and their respective annual effective dose rates produced by ${ }^{226} \mathrm{Ra},{ }^{232} \mathrm{Th}$ and ${ }^{40} \mathrm{~K}$ were measured by using high purity germanium (HPGe) detector of relative efficiency $20 \%$. The activity concentrations of ${ }^{226} \mathrm{Ra},{ }^{232} \mathrm{Th}$ and ${ }^{40} \mathrm{~K}$ in the sand samples were found to vary from $22.83 \pm 4.11$ to 100.21 $\pm 2.39 \mathrm{BqKg}^{-1}, 68.76 \pm 2.86 \mathrm{BqKg}^{-1}$ to $297.37 \pm 4.32 \mathrm{BqKg}^{-1}$ and $75.87 \pm 15.75$ to 161.81 $\pm 19.90 \mathrm{BqKg}^{-1}$ with mean values $48.76,126.11$ and $292.38 \mathrm{Bqkg}^{-1}$, respectively. For sediment samples the corresponding radionuclides ranged between $12.11 \pm 1.99$ and $31.64 \pm 1.64 \mathrm{BqKg}^{-1}, 18.94 \pm 1.90 \mathrm{BqKg}^{-1}$ and $71.11 \pm 2.88 \mathrm{BqKg}^{-1}$ and $182.73 \pm 19.81$ $\mathrm{BqKg}^{-1}$ and $345.77 \pm 21.07 \mathrm{BqKg}^{-1}$, with mean values $19.67,32.13$ and $243.38 \mathrm{Bqkg}^{-1}$, respectively. The absorbed dose rate was estimated to the range from 30.50 to 242.93 $\mathrm{nGyh}^{-1}$ with an average value of $74.87 \mathrm{nGyh}^{-1}$. The estimated outdoor annual effective dose varied between 0.22 and $1.79 \mathrm{mSv} /$ year with a mean value of $0.55 \mathrm{mSv} /$ year, which is higher than the world average for outdoor annual effective dose $(0.07 \mathrm{mSv} / \mathrm{year})$. The external hazard indices for the samples varied from 0.17 to 1.43 with the average value of 0.44 , which is less than the unity. The average value of radium equivalent activity was estimated and found to be $161.40 \mathrm{BqKg}^{-1}$ which is less than the acceptable limit of world average value of $370 \mathrm{BqKg}^{-1}$.
\end{abstract}

Key words: Sediment, Gamma ray spectrometry, Radiological hazard, Effective dose, Kuakata, Calibration

\section{INTRODUCTION}

Natural radioactivity is widespread in the earth's environment and it exists in various geological formations like soils, rocks, plants, sand, water and air. Hence, humans should be aware of their natural environment with regard to the radiation effects due to the naturally occurring and induced radioactive elements. Natural background radiation is the combined radiation field produced by the primordial and cosmogenic radioactive materials around us plus cosmic radiation from space. There are few areas in the world

* Corresponding author: <skdas252002@yahoo.com>.

${ }^{1}$ Health Physics Division, Atomic Energy Center, Dhaka, Bangladesh. 
such as Brazil, China, India, Austria, France and Iran (Roessier et al. 1990) where the background radiation levels were found to be high, varying over an order of magnitude depending upon the site-specific terrestrial radioactivity. The assessment of gamma radiation dose from natural sources is of particular importance as natural radiation is the largest contributor to the external dose of the world population (Pfennig 1995). An attempt is made in this paper to determine the activity concentration of ${ }^{226} \mathrm{Ra},{ }^{232} \mathrm{Th}$ and ${ }^{40} \mathrm{~K}$ in beach sand and sediment samples collected from Kuakata seashore of Patuakhali using high purity germanium (HPGe) detector of relative efficiency $20 \%$ and to compute the total absorbed gamma-dose rate in air due to the presence of ${ }^{238} \mathrm{U}$ series, ${ }^{232} \mathrm{Th}$ series and ${ }^{40} \mathrm{~K}$ in the samples (Turner 1995).

\section{MATERIALS AND METHODS}

Twenty samples consisting of shore sand and sediments were collected from different sites along the coast of the Kuakata sea beach of Patuakhali (during 1st to 4th January, 2014). At each site about 1 to $1.25 \mathrm{~kg}$ samples of shore were successively collected at a depth of 0.20 $\mathrm{m}(20 \mathrm{~cm})$ from the surface at intervals of $0.5 \mathrm{~km}$ and transferred into polyethylene bags and labeled accordingly. The coordinates of the sampling area is in between $21^{\circ} 52^{\prime} 25.42^{\prime \prime} \mathrm{N}$ and $21^{\circ} 51^{\prime} 54.33^{\prime \prime} \mathrm{N}$ and $90^{\circ} 6^{\prime} 31.06^{\prime \prime} \mathrm{E}$ and $90^{\circ} 15^{\prime} 53.31^{\prime \prime} \mathrm{E}$ (Fig. 1). The samples were then transported, stored and processed at the sample preparation laboratory of Bangladesh Atomic Energy Center, Dhaka. The samples were cleaned for stones, gravels, grass-roots, vegetation etc. and then dried in the sun for several days. The samples were then crushed and ground to fine grains using a grinding machine. The samples were mixed homogeneously and passed through a sieve of $200 \mu \mathrm{m}$ mesh size. The samples were dried again in a temperature controlled oven at $104^{\circ} \mathrm{C}$ temperature for 24 hours in order to eliminate any traces of water. Upon drying the samples were transferred to sealable cylindrical plastic containers of $7 \mathrm{~cm}$ height and $5.5 \mathrm{~cm}$ in diameter and the weights of the samples were recorded using an electrical balance. The sample-filled plastic containers were sealed tightly with cap and wrapped with thick vinyl tape around their necks; marked individually with identification number, sample location, date of preparation and net weight and then stored for about 30 days to assume secular equilibrium between ${ }^{238} \mathrm{U}$ and ${ }^{232} \mathrm{Th}$ series and their daughter progenies (Ahmed et al. 2014).

The detection and measurement of radionuclides in the samples were carried out by gamma spectrometry system using a p-type co-axial HPGe detector of $93 \mathrm{~cm}^{3}$ active volume and $20 \%$ relative efficiency supplied by CANBERRA. The co-axial geometry with electrical contacts in the form of concentric cylinders closed at the end makes it possible to produce very large volume detector elements with excellent efficiencies for high-energy photons. 


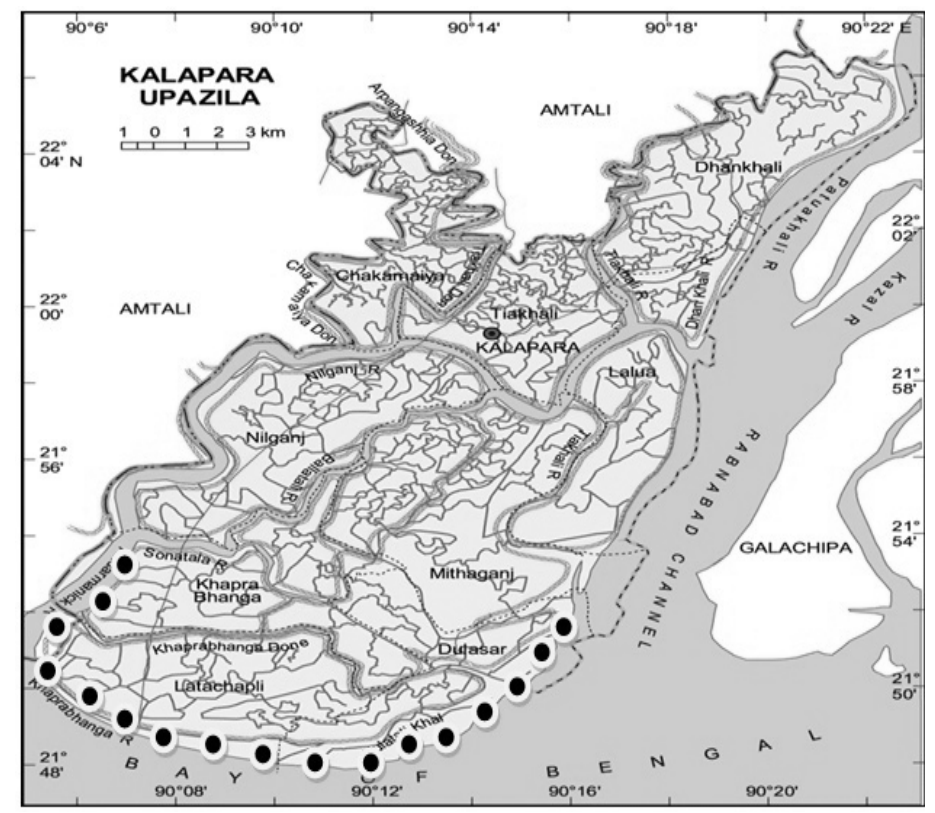

Fig. 1. Location map of sampling (using Google map) at the Kuakata sea beach, Patuakhali, Bangladesh.

The HPGe had a resolution of $2 \mathrm{keV}$ at $1332 \mathrm{keV}$ of Cobalt-60 gamma-ray line. The detector was coupled to a $16 \mathrm{k}$-channel analyser. The spectra of all samples were perfectly analysed using Genie-2000 spectra analysis software (which matched various gamma energy peaks to a library of all possible radionuclides) to calculate the concentrations of ${ }^{226} \mathrm{Ra},{ }^{232} \mathrm{Th}$ and ${ }^{40} \mathrm{~K}$. The detector was enclosed in a cylindrical shielding container made of lead and iron and having a moving cover to reduce the external gamma-ray background. All the samples were counted for $5 \mathrm{ks}$. Prior to the measurement of the samples, the environmental gamma background at the laboratory site was determined with an identical empty plastic container used in the sample measurement. The energy regions selected for the corresponding radionuclides were 295 and $352 \mathrm{keV}$ of ${ }^{214} \mathrm{~Pb}$ and 609,1120 and $1764 \mathrm{keV}$ for ${ }^{214} \mathrm{Bi}$ for ${ }^{226} \mathrm{Ra}, 583$ and $2614 \mathrm{keV}$ of ${ }^{208} \mathrm{Tl}, 911$ and $969 \mathrm{keV}$ of ${ }^{228} \mathrm{Ac}$ for ${ }^{232} \mathrm{Th}$ and $1460 \mathrm{keV}$ for ${ }^{40} \mathrm{~K}$ (Roessier et al. 1970).

Calibration of the detector: The efficiency calibration of the detector was carried out by standard source of solid matrix prepared using ${ }^{226} \mathrm{Ra}$ standard solution. The standard source was prepared using identical container used for the measurement of the samples. The preparation process of standard sources had been reported elsewhere (Harb et al. 2008). The energy calibration of the detector was performed by ${ }^{137} \mathrm{Cs}$ and ${ }^{60} \mathrm{Co}$ point sources.

The activity concentration (A) of each radionuclide in the samples was determined by using the net count (cps) (obtained by subtracting the background counts from the 
gross counts with same counting time under the selected photo peaks), weight of the sample, the photo-peak efficiency and the gamma intensity at a specific energy as (UNSCEAR 2000)

$$
A=\frac{c p s \times 1000}{\varepsilon \times I \times W} \times 100
$$

where, $\mathrm{A}=$ activity of the sample in $\mathrm{Bqkg}^{-1}$

cps $=$ the net counts per second $=$ cps for the sample - cps for the background value

$\varepsilon=$ the counting efficiency $(\%)$ of the gamma energy

$\mathrm{I}=$ absolute intensity of the gamma ray and

$\mathrm{W}=$ samples net weight (in gm).

The errors in the measurement have been expressed in terms of standard deviation $( \pm 2 \sigma)$, where $\sigma$ is expressed as (Knoll 1998)

$$
\sigma=\left[N_{s} / T_{s}{ }^{2}+N_{b} / T_{b}{ }^{2}\right]^{\frac{1}{2}}
$$

where, $\mathrm{N}_{\mathrm{s}}$ is the counts measured in time $\mathrm{T}_{\mathrm{s}}$ and $\mathrm{N}_{\mathrm{b}}$ is the background counts measured in the $T_{b}$. The standard deviation $( \pm 2 \sigma)$, in cps was converted into activity in $\mathrm{Bqkg}^{-1}$ according to equation (1).

Calculation of radiological hazard: Radiological impacts of the radionuclides found in the samples were calculated on the basis of calculation of radium equivalent activity, dose rate calculation, and effective dose rate and hazard indices as following.

The radionuclides ${ }^{226} \mathrm{Ra},{ }^{232} \mathrm{Th}$ and ${ }^{40} \mathrm{~K}$ are not homogeneously distributed in soil, sand and sediments samples. The inhomogeneous distribution from naturally occurring radionuclides is due to disequilibrium between ${ }^{226} \mathrm{Ra}$ and its decay products. For uniformity in exposure estimates, the radionuclide concentrations are defined in terms of 'Radium equivalent activity' $\left(\mathrm{Ra}_{\mathrm{eq}}\right)$ in $\mathrm{Bqkg}^{-1}$. This allows comparison of the specific activity of materials containing different amounts of ${ }^{226} \mathrm{Ra},{ }^{232} \mathrm{Th}$ and ${ }^{40} \mathrm{~K}$ is given as follows (Beretka and Mathew 1985).

$$
\mathrm{Ra}_{\mathrm{eq}}\left(\mathrm{Bqkg}^{-1}\right)=\mathrm{C}_{\mathrm{Ra}}+1.43 \mathrm{C}_{\mathrm{Th}}+0.077 \mathrm{C}_{\mathrm{K}}
$$

where, $\mathrm{C}_{\mathrm{Ra}}, \mathrm{C}_{\mathrm{Th}}$ and $\mathrm{C}_{\mathrm{K}}$ are the specific activities of ${ }^{226} \mathrm{Ra},{ }^{232} \mathrm{Th}$ and ${ }^{40} \mathrm{~K}$, respectively in $\mathrm{Bqkg}^{-1}$.

The absorbed dose rate was calculated from the measured activities of ${ }^{226} \mathrm{Ra},{ }^{232} \mathrm{Th}$ and ${ }^{40} \mathrm{~K}$ in the surface soil, sand and sediment samples using the formula given below (UNSCEAR 2000). 


$$
\mathrm{D}\left(\mathrm{nGyh}^{-1}\right)=0.462 \mathrm{C}_{\mathrm{Ra}}+0.604 \mathrm{C}_{\mathrm{Th}}+0.042 \mathrm{C}_{\mathrm{K}}
$$

where, $\mathrm{D}$ is absorbed dose rate $\left(\mathrm{nGyh}^{-1}\right), \mathrm{C}_{\mathrm{Ra}}, \mathrm{C}_{\mathrm{Th}}$, and $\mathrm{C}_{\mathrm{K}}$ are the activity concentrations $\left(\mathrm{Bqkg}^{-1}\right)$ of ${ }^{226} \mathrm{Ra},{ }^{232} \mathrm{Th}$ and ${ }^{40} \mathrm{~K}$, respectively. In natural environmental radioactivity situations, the effective dose is calculated from the absorbed dose by applying the factor is $0.7 \mathrm{~Sv} / \mathrm{Gy}$ (UNSCEAR 1993).

To estimate the annual effective dose rate, the conversion co-efficient from absorbed dose, $0.7 \mathrm{SvGy}^{-1}$ and outdoor occupancy factor 0.2 proposed by UNSCEAR (2000) were used by considering that the people on the average, spent $20 \%$ of their time outdoors (Debertin and Helmer 1988).

The effective dose rate in units of $\mathrm{mSvy}^{-1}$ was calculated by the following formula:

Effective dose rate, $\mathrm{E}\left(\mathrm{mSvy}^{-1}\right)=\mathrm{D}\left(\mathrm{nGyh}^{-1}\right) \times 8760 \mathrm{~h} \times 0.2 \times 0.7 \mathrm{SvGy}^{-1} \times 10^{-6}$

The external hazard index, $\mathrm{H}_{\mathrm{ex}}$, is defined as ( $\mathrm{Lu}$ and Xiolan 2006).

$\mathrm{H}_{\mathrm{ex}}=\left(\mathrm{C}_{\mathrm{Ra}} / 370+\mathrm{C}_{\mathrm{Th}} / 259+\mathrm{C}_{\mathrm{k}} / 4810\right) \leq 1$

where, $\mathrm{C}_{\mathrm{Ra}}, \mathrm{C}_{\mathrm{Th}}$ and $\mathrm{C}_{\mathrm{K}}$ are the activity concentrations $\left(\mathrm{Bqkg}^{-1}\right)$ of ${ }^{226} \mathrm{Ra},{ }^{232} \mathrm{Th}$ and

${ }^{40} \mathrm{~K}$, respectively. The value of this index must be less than unity in order to keep the radiation hazard insignificant. The maximum value of $\mathrm{H}_{\mathrm{ex}}$ equal to unity corresponds to the upper limit of radium equivalent activity $\left(370 \mathrm{Bqkg}^{-1}\right)$.

\section{RESULTS AND DISCUSSION}

The results of the present study on the two types (Sand and sediment) of samples are summarized in the following sections.

The activity concentrations of ${ }^{226} \mathrm{Ra},{ }^{232} \mathrm{Th}$ and ${ }^{40} \mathrm{~K}$ of all the samples were calculated in $\mathrm{Bqkg}^{-1}$ with a counting error of two sigma $( \pm 2 \sigma)$ and are shown in the Table 1 and 2 . The bar diagrams (Figs 3 and 4) show the distribution of the concentrations of all the radionuclides present in the collected samples.

The activity concentrations of ${ }^{226} \mathrm{Ra},{ }^{232} \mathrm{Th}$, and ${ }^{40} \mathrm{~K}$ in sand samples were found to vary between $22.82 \pm 4.11$ and 100.21 $\pm 2.39 \mathrm{Bqkg}^{-1}, 68.00 \pm 2.86$ and $297.37 \pm 4.32 \mathrm{Bqkg}^{-1}$ and $75.87 \pm 15.8$ and $161.81 \pm 19.9 \mathrm{Bqkg}^{-1}$ with the average values of $48.76 \pm 5.29,126.11$ \pm 3.31 and $292.38 \pm 18.24 \mathrm{Bqkg}^{-1}$, respectively. The average values agreed well with results obtained in earlier studies (Khondaker et al. 2012). In Kuakata sea-beach, the concentration of ${ }^{226} \mathrm{Ra}$ is about similiar those found in sand samples of Kuakata.

The activity concentrations of ${ }^{226} \mathrm{Ra},{ }^{232} \mathrm{Th}$, and ${ }^{40} \mathrm{~K}$ in sediment samples ranged from $12.77 \pm 1.33$ to $31.64 \pm 1.64 \mathrm{Bqkg}^{-1}, 18.93 \pm 1.90$ to $71.10 \pm 2.88 \mathrm{Bqkg}^{-1}$ and $182.32 \pm$ 
19.8 to $345.77 \pm 21.1 \mathrm{~Bq} \cdot \mathrm{kg}^{-1}$ with an average of $19.67 \pm 2.52,32.13 \pm 2.13$ and $243.57 \pm$ $21.1 \mathrm{Bqkg}^{-1}$, respectively. These average values agreed well with the result obtained in earlier studies (Alamgir et al. 2012). Moreover, the values of activity concentrations of ${ }^{226} \mathrm{Ra}$ and ${ }^{232} \mathrm{Th}$ found in the present study for sand samples were higher than the worldwide average value of 35 and $30 \mathrm{Bqkg}^{-1}$, on the other hand for sediment samples the values were lower compared to world average value. The activity concentration of ${ }^{40} \mathrm{~K}$ for all sample were lower than the world average value $400 \mathrm{Bqkg}^{-1}$ (UNSCEAR 2000).

Table 1. Activity concentration in $\mathrm{Bqkg}^{-1}$ in different sand samples of Kuakata beach.

\begin{tabular}{|c|c|c|c|}
\hline \multirow{2}{*}{ Sample ID } & \multicolumn{3}{|c|}{ Activity concentration $\mathrm{Bqkg}^{-1}$} \\
\hline & ${ }^{226} \mathrm{Ra}$ & ${ }^{232} \mathrm{Th}$ & ${ }^{40} \mathrm{~K}$ \\
\hline KKSAND01 & $48.52 \pm 1.79$ & $109.63 \pm 3.44$ & $105.53 \pm 19.1$ \\
\hline KKSAND02 & $40.05 \pm 3.91$ & $95.19 \pm 2.94$ & $161.81 \pm 19.9$ \\
\hline KKSAND03 & $32.97 \pm 3.82$ & $69.08 \pm 2.62$ & $87.00 \pm 19.3$ \\
\hline KKSAND04 & $42.29 \pm 2.56$ & $116.61 \pm 3.00$ & $114.94 \pm 17.6$ \\
\hline KKSAND05 & $100.21 \pm 2.39$ & $297.37 \pm 4.32$ & $75.87 \pm 15.8$ \\
\hline KKSAND06 & $53.22 \pm 3.13$ & $83.23 \pm 2.71$ & $97.62 \pm 18.7$ \\
\hline KKSAND07 & $22.82 \pm 4.11$ & $68.00 \pm 2.86$ & $114.97 \pm 19.0$ \\
\hline KKSAND08 & $41.41 \pm 4.64$ & $147.45 \pm 3.90$ & $153.35 \pm 19.5$ \\
\hline KKSAND09 & $57.79 \pm 23.02$ & $146.01 \pm 4.28$ & $103.29 \pm 17.1$ \\
\hline KKSAND10 & $48.37 \pm 3.52$ & $127.72 \pm 3.01$ & $86.28 \pm 16.4$ \\
\hline Av. & $48.76 \pm 5.29$ & $126.11 \pm 3.31$ & $292.38 \pm 18.24$ \\
\hline World av. & 35 & 30 & 400 \\
\hline
\end{tabular}

Table 2. Activity concentration in $\mathrm{Bqkg}^{-1}$ in different sediment samples of Kuakata beach.

\begin{tabular}{llll}
\hline \multirow{2}{*}{ Sample ID } & \multicolumn{3}{c}{ Activity concentration Bq/kg } \\
\cline { 2 - 4 } & ${ }^{226} \mathrm{Ra}$ & ${ }^{232} \mathrm{Th}$ \\
\hline KKSEDI01 & $21.3 \pm 2.72$ & $23.53 \pm 2.03$ & $182.7 \pm 19.8$ \\
KKSEDI02 & $23.50 \pm 4.05$ & $71.10 \pm 2.88$ & $195.03 \pm 20.0$ \\
KKSEDI03 & $31.64 \pm 1.64$ & $47.42 \pm 2.39$ & $254.97 \pm 20.4$ \\
KKSEDI04 & $13.83 \pm 3.96$ & $22.15 \pm 1.86$ & $315.80 \pm 22.3$ \\
KKSEDI05 & $12.11 \pm 1.99$ & $28.65 \pm 2.04$ & $233.19 \pm 22.7$ \\
KKSEDI06 & $12.77 \pm 1.33$ & $30.04 \pm 2.17$ & $231.42 \pm 21.3$ \\
KKSEDI07 & $29.31 \pm 1.68$ & $18.93 \pm 1.90$ & $246.95 \pm 21.5$ \\
KKSEDI08 & $13.73 \pm 4.24$ & $21.10 \pm 1.98$ & $247.53 \pm 22.4$ \\
KKSEDI09 & $20.60 \pm 2.26$ & $32.73 \pm 2.17$ & $345.77 \pm 21.1$ \\
KKSEDI10 & $17.86 \pm 1.33$ & $25.61 \pm 1.88$ & $182.32 \pm 19.8$ \\
Av. & $19.67 \pm 2.52$ & $32.13 \pm 2.13$ & $243.57 \pm 21.1$ \\
World av. & 35 & 30 & 400 \\
\hline
\end{tabular}


Radiological indices: The radiological parameters such as indices of radium equivalent activity $\left(\mathrm{Ra}_{\mathrm{eq}}\right)$, absorbed dose rate (D), outdoor annual effective dose (E), and external hazard index $\left(\mathrm{H}_{\mathrm{ex}}\right)$ were calculated to estimate the radiological risk due to the presence of ${ }^{226} \mathrm{Ra},{ }^{232} \mathrm{Th}$ and ${ }^{40} \mathrm{~K}$ in the samples. Table 3 shows the values of $\mathrm{Ra}_{\mathrm{eq}}, \mathrm{D}, \mathrm{E}$, and $\mathrm{H}_{\mathrm{ex}}$.

The values of radium equivalent activity sand and sediment samples were found to vary from 130.01 to $531.31 \mathrm{Bqkg}^{-1}$ and 62.93 to $139.26 \mathrm{Bqkg}^{-1}$, with an average of 237.58 and $83.82 \mathrm{Bqkg}^{-1}$, respectively which were lower than the world average value of 370 $\mathrm{Bqkg}^{-1}$ (UNSCEAR 2000) reported by OECD. However, KKSAND05 showed significantly higher values of radium equivalent activity.

The calculated values of external hazard index for sand and sediment samples ranged from 0.35 to 1.43 and 0.17 to 0.38 , with an average of 0.64 and 0.28 . These were lower than the world wide average value 1 (UNSCEAR 2000).

Table 3. Absorbed dose rate (D), outdoor annual effective dose (E), radium equivalent activity $\left(\mathrm{Ra}_{\mathrm{eq}}\right)$ and external hazard index $\left(\mathrm{H}_{\mathrm{ex}}\right)$ of the samples collected from Kuakata beach.

\begin{tabular}{cllllllll}
\hline $\begin{array}{c}\text { Sample } \\
\text { ID }\end{array}$ & $\begin{array}{l}\text { Radium } \\
\text { equivalent } \\
\text { activity }\end{array}$ & $\begin{array}{l}\text { Internal } \\
\text { hazard } \\
\text { index }\end{array}$ & $\begin{array}{l}\text { External } \\
\text { hazard } \\
\text { index }\end{array}$ & $\begin{array}{c}\text { Abd } \\
\text { (D out) }\end{array}$ & $\begin{array}{c}\text { Abd } \\
\text { (D in) }\end{array}$ & $\begin{array}{c}\text { E } \\
\text { (in) }\end{array}$ & $\begin{array}{c}\text { E } \\
\text { (out) }\end{array}$ & $\begin{array}{c}\text { Effective } \\
\text { dose(E) }\end{array}$ \\
\hline KKSAND01 & 213.44 & 0.71 & 0.58 & 97.86 & 117.43 & 0.58 & 0.14 & 0.72 \\
KKSAND02 & 188.64 & 0.62 & 0.51 & 87.11 & 104.54 & 0.51 & 0.13 & 0.64 \\
KKSAND03 & 138.46 & 0.46 & 0.37 & 63.57 & 76.29 & 0.37 & 0.09 & 0.47 \\
KKSAND04 & 217.90 & 0.70 & 0.59 & 100.22 & 120.27 & 0.59 & 0.15 & 0.74 \\
KKSAND05 & 531.31 & 1.71 & 1.43 & 242.93 & 291.52 & 1.43 & 0.36 & 1.79 \\
KKSAND06 & 179.78 & 0.63 & 0.49 & 82.05 & 98.46 & 0.48 & 0.12 & 0.60 \\
KKSAND07 & 130.01 & 0.41 & 0.35 & 60.23 & 72.28 & 0.35 & 0.09 & 0.44 \\
KKSAND08 & 264.09 & 0.83 & 0.71 & 121.93 & 146.31 & 0.72 & 0.18 & 0.90 \\
KKSAND09 & 274.55 & 0.90 & 0.74 & 125.80 & 150.96 & 0.74 & 0.19 & 0.93 \\
KKSAND10 & 237.67 & 0.77 & 0.64 & 108.94 & 130.73 & 0.64 & 0.16 & 0.80 \\
Av. & 237.58 & 0.77 & 0.64 & 109.07 & 130.88 & 0.64 & 0.16 & 0.80 \\
KKSEDI01 & 63.45 & 0.23 & 0.17 & 29.44 & 35.33 & 0.17 & 0.04 & 0.22 \\
KKSEDI02 & 139.26 & 0.44 & 0.38 & 65.00 & 78.00 & 0.38 & 0.10 & 0.48 \\
KKSEDI03 & 114.48 & 0.39 & 0.31 & 53.33 & 64.00 & 0.31 & 0.08 & 0.39 \\
KKSEDI04 & 65.15 & 0.21 & 0.18 & 31.59 & 37.91 & 0.19 & 0.05 & 0.23 \\
KKSEDI05 & 77.40 & 0.24 & 0.21 & 37.78 & 45.34 & 0.22 & 0.06 & 0.28 \\
KKSEDI06 & 73.70 & 0.23 & 0.20 & 35.42 & 42.51 & 0.21 & 0.05 & 0.26 \\
KKSEDI07 & 74.21 & 0.28 & 0.20 & 35.05 & 42.06 & 0.21 & 0.05 & 0.26 \\
KKSEDI08 & 62.93 & 0.21 & 0.17 & 30.50 & 36.61 & 0.18 & 0.04 & 0.22 \\
KKSEDI09 & 86.47 & 0.29 & 0.23 & 41.16 & 49.39 & 0.24 & 0.06 & 0.30 \\
KKSEDI10 & 81.12 & 0.27 & 0.22 & 39.52 & 47.43 & 0.23 & 0.06 & 0.29 \\
Av. & 83.82 & 0.28 & 0.23 & 39.88 & 47.86 & 0.23 & 0.06 & 0.29 \\
\hline
\end{tabular}

The absorbed dose rate due to the terrestrial gamma rays at $1 \mathrm{~m}$ above from the ground were in the range of 60.23 to $242.93 \mathrm{nGyh}^{-1}$ for sand samples and 30.50 to 65.00 $\mathrm{nGyh}^{-1}$ for sediment samples with the average values of 109.07 and $39.88 \mathrm{nGyh}^{-1}$, 
respectively. The values for sand samples are significantly higher than the world average value of $55 \mathrm{nGyh}^{-1}$ (Abdil et al. 2006) and for sediment samples it was lower than the world average values.

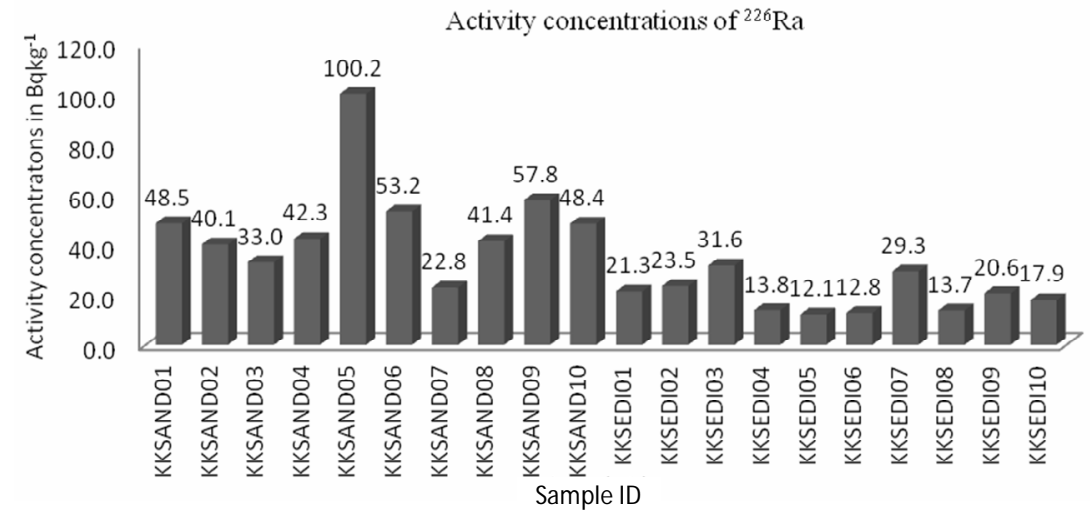

Fig. 2. Distribution of ${ }^{226} \mathrm{Ra}$ in all samples of Kuakata beach, Patuakhali, Bangladesh.

The outdoor annual effective dose equivalent was calculated from the air absorbed doses using the relation given in Eq. (5). The values varied from 0.09 to $0.36 \mathrm{mSvy}^{-1}$ and 0.04 to $0.16 \mathrm{mSvy}^{-1}$ and with the mean values of 0.16 and $0.06 \mathrm{mSvy}^{-1}$ for sand and sediment samples, respectively. The values in sand samples were higher than those of the worldwide average values for outdoor annual effective dose of $0.07 \mathrm{mSvy}^{-1}$ (UNSCEAR 2000) and for sediment samples it was lower than the world average value.

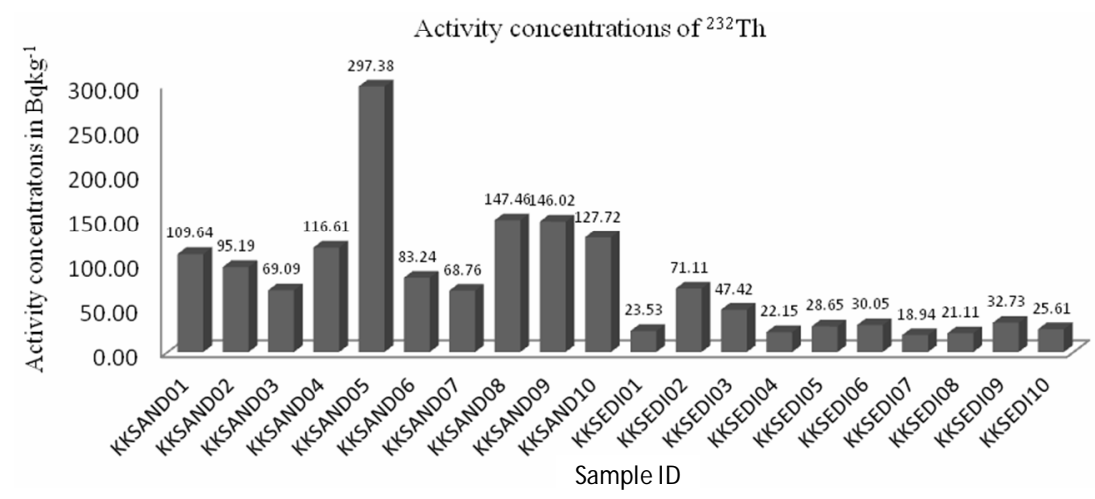

Fig. 3. Distribution of ${ }^{232}$ Th in all samples of Kuakata beach, Patuakhali, Bangladesh.

The values of hazard index (in some samples), absorbed dose rate and annual effective dose found in the present study exceed the standard limits for radiological safety. Therefore, though insignificant, these environmental components may produce higher radiation exposure effect to the public living around the area than the other part of the country. As tourist stay for short period, it is not hazardous for them. 


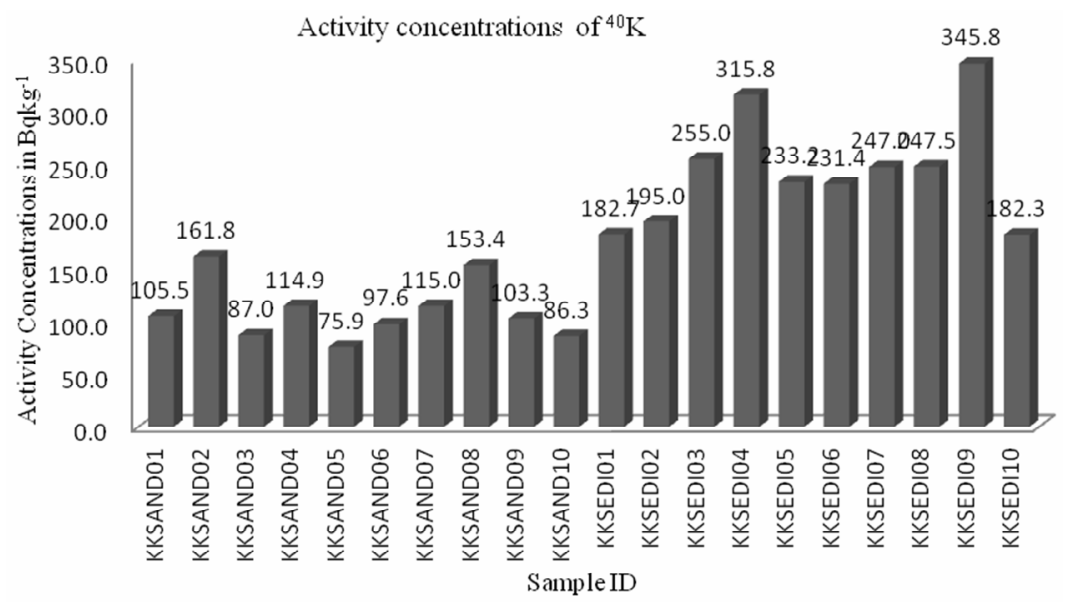

Fig. 4. Distribution of ${ }^{40} \mathrm{~K}$ in all samples of Kuakata beach, Patuakhali, Bangladesh.

Correlations between the radionuclide: The correlation of naturally occurring radionuclides have been shown in Figs 5, 6 and $7 .{ }^{226} \mathrm{Ra}$ and ${ }^{232} \mathrm{Th}$ were strongly correlated with correlation coefficient $\mathrm{R}^{2}$ value of 0.878 . This strong correlation between ${ }^{232} \mathrm{Th}$ and ${ }^{226} \mathrm{Ra}$ might be due to their some similarities in environmental origin (Mamoney et al. 2004). A good correlation between ${ }^{226} \mathrm{Ra}$ and ${ }^{232} \mathrm{Th}$ is shown in Fig. 5.

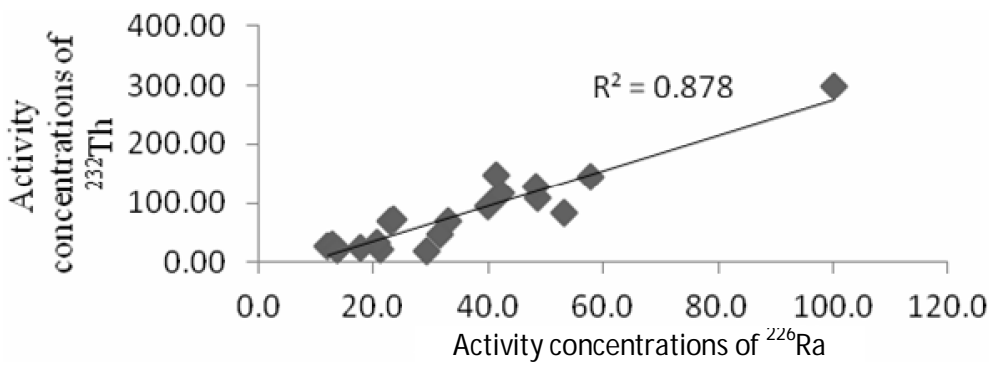

Fig. 5. Correlation between activity concentrations of ${ }^{226} \mathrm{Ra}$ and ${ }^{232} \mathrm{Th}$ in all samples.

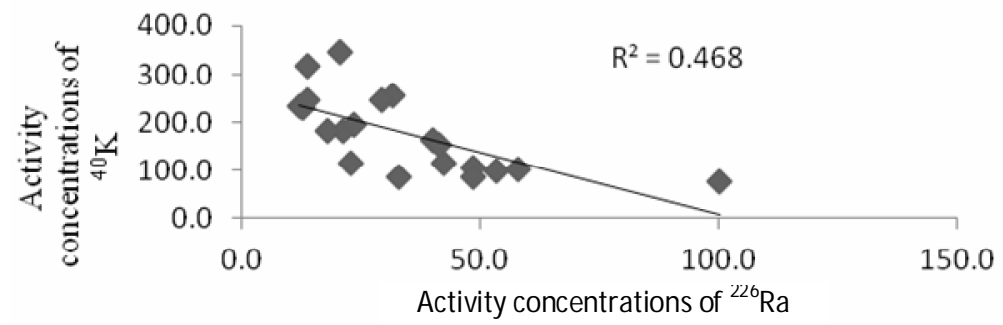

Fig. 6. Correlation between activity concentrations of ${ }^{226} \mathrm{Ra}$ and ${ }^{40} \mathrm{~K}$ in all samples. 
The relationship between ${ }^{226} \mathrm{Ra}$ and ${ }^{40} \mathrm{~K}$, was weak with correlation coefficient of 0.46 . The weak correlation $(0.46)$ between radium and potassium might be explained due to high potassium solubility (Mamoney et al. 2004). The weak correlation existed between ${ }^{232} \mathrm{Th}$ and ${ }^{40} \mathrm{~K}$ in the samples $\left(\left(\mathrm{R}^{2}=0.456\right)\right.$ shown in Fig. 7 , which indicated ${ }^{40} \mathrm{~K}$ concentrations might not be related to the presence of ${ }^{232} \mathrm{Th}$ (Harb et al. 2008).

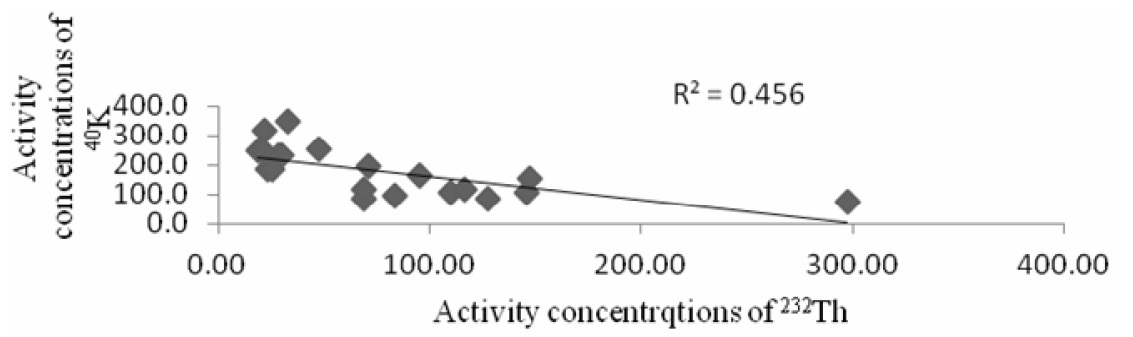

Fig. 7. Correlation between activity concentrations of ${ }^{232} \mathrm{Th}$ and ${ }^{40} \mathrm{~K}$ in all samples.

\section{CONCLUSION}

The activity concentrations and radiological hazard associated with beach sand and sediment samples collected from Kuakata beach, Patuakhali of Bangladesh were investigated in the present study. The results indicated that only the natural radionuclides were present in the samples. The radioactivity concentrations of ${ }^{226} \mathrm{Ra},{ }^{232} \mathrm{Th}$ and ${ }^{40} \mathrm{~K}$ were similar to the world average values. However, the activity levels in sand samples were also significantly higher than the other parts of the country. The calculated average absorbed dose rate and estimated outdoor annual effective dose were found higher than the worldwide average values for sand samples. The average radium equivalent activity $\left(\mathrm{R}_{\mathrm{eq}}\right)$ and external hazard $\left(\mathrm{H}_{\mathrm{ex}}\right)$ indices were less than the world average values. Therefore, the probability of the radiological impact on the inhabitants/public living in this area will be insignificant. It is not also hazardous for tourist because they stay for short period in the concerning area.

\section{REFERENCES}

Abdil, M. R., H. Faghihian, M. Kamali, M. Mostajbod-davati and A. Hasanzadeh. 2006. Distribution of natural radionuclides on coasts of Bushehr, Persian Gulf, Iran. Iranian J. Science \& Technology: Transaction A. 30: 259-269.

Ahmed, M.M., S. K. Das, M. A. Haydar, M. M. H. Bhuiyan, M. I. Ali and D. Paul. 2014. Study of natural radioactivity and radiological hazard of sand, sediment, and soil samples from Inani beach, Cox's Bazar, Bangladesh. J. Nuclear and Particle Physics 4(2): 69-78.

Alamgir Miah, M. M. H. Miah, Masud Kamal, M. I. Chowdhury and M. Rahmatullah. 2012. Soil Samples of Malnichera Tea Garden in Sylhet District of Bangladesh. J. Nuclear and Particle Physics 2(6): 147-152.

Beretka, J. and P.J. Mathew. 1985. Natural radioactivity of Australian buildings, materials, industrial wastes and by products. Health Physic. 48: 87-95. 
Debertin, K. and R.G. Helmer. 1988. Gamma and X-ray spectrometry detectors, North Holland.

Harb, S., K. S. Din and A. Abbady. 2008. Study of efficiency calibrations of HPGe detectors for radioactivity measurement of environmental samples. Proceedings of the 3rd Environmental Physics Conference, 19-23 Feb., Aswan, Egypt.

Harb, S. 2008. Natural radioactivity and external gamma radiation exposure at the costal Red Sea in Egypt. Radiation Protection Dosimetry 130(3): 376-384.

Kannan, V., M. P. Rajan, M. A. Lyengar, and R. Ramesh. 2002. Distribution of natural and anthropogenic radionuclides in soil and beach sand samples of Kalpakkam (India). Appl. Rodiat. Isot. 57: 109-119.

Knoll, G. F. 1998. Radiation Detection and Measurement, $3^{\text {rd }}$ edition, New York.

Khondaker Mohammed Nazrul Islam, Debasish Paul, Md. Mahbubur Rahman Bhuiyan, Amina Akter, Budrun Neher and Sheikh Mohammad Azharul Islam. 2012. Study of environmental radiation on sand and soil samples from Kuakata sea beach of Patuakhali. J. Environmental Protection 3: 1078-1084.

Lu, X. and Z. Xiolan. 2006. Measurement of natural radioactivity in sand samples collected from the Booje Weithe sand park, China, Environ. Geol. 5: 977-988.

Mamoney, M.H., El Ashraf and E.M. Khater. 2004. Environmental characterization and radioecological impacts of NON-nuclear industries on the Red Sea coast. J. Environmental Radioactivity 73: 151-168.

Morneburg Nachtigall Persico G. Pfennig, H. Klewe-Nebenius, W. Seelmann-Eggebert, Forschungszentrum Karlsruhe. 1995. 6. Auflage.

Roessier, C.E., Z.A. Smith, W.E. Bloch and R.J. Prince. 1970. Uranium and radium in floride phosphate materials. Health Phys. 37: 269-277.

Turner, J. E. 1995. Atoms, radiation and radiation protection. John Wiley, New York. pp. 1-13.

United Nations Scientific Committee on the Effects of Atomic Radiation (UNSCEAR), Sources, Effects and Risks of Ionising Radiation. 1988. United Nations, New York.

UNSCEAR. 1993. Sources and Effects of Ionizing Radiation. United Nations Scientific Committee on the Effects of Atomic Radiation. United Nations, New York.

UNSCEAR. 2000. Sources and effects of ionizing radiation, Report of the United Nations Scientific Committee on the Effects of Atomic Radiation to the General Assembly. United Nations, New York, USA.

(Received revised manuscript on 5 April, 2016) 